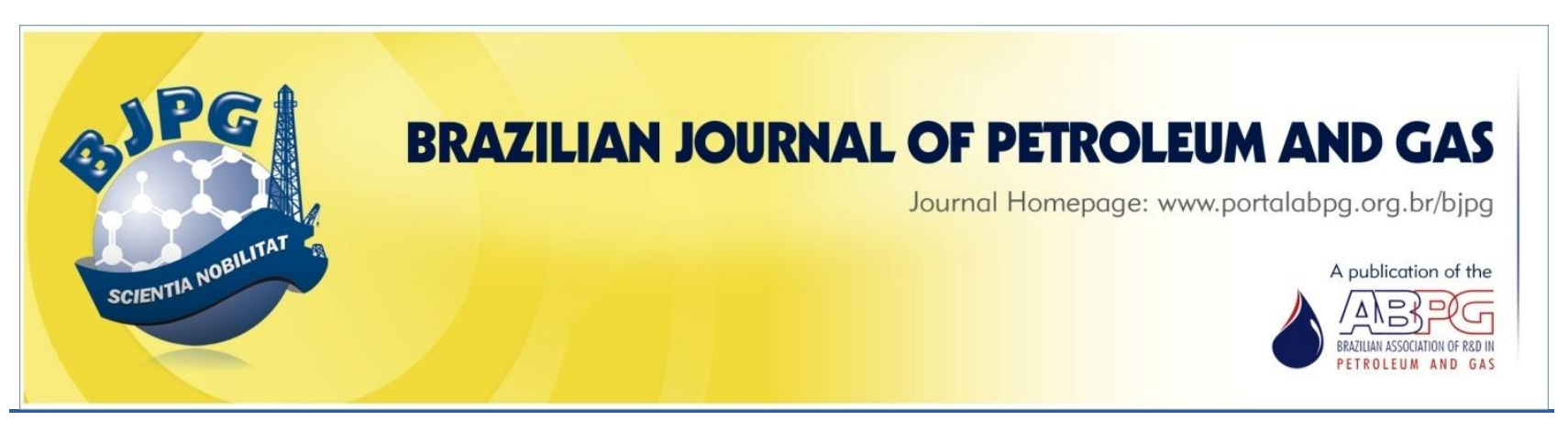

\title{
OIL REMOVAL FROM OILFIELD PRODUCED WATER BY SAND FILTER
}

\author{
${ }^{a}$ Carvalho, P. C. A. P.; ${ }^{b}$ Foletto, E. L. ${ }^{1}{ }^{a}$ Barros Neto, E. L.; ${ }^{a}$ Chiavone-Filho, 0. \\ a Department of Chemical Engineering, Federal University of Rio Grande do Norte, Natal-RN, Brazil \\ ${ }^{b}$ Department of Chemical Engineering, Federal University of Santa Maria, Santa Maria-RS, Brazil
}

Received: 31.05.2016 / Revised: 16.06.2016 / Accepted: 20.06.2016 / Published on line: 04.10.2016

\begin{abstract}
The aim of this work is to examine the performance of a glass column filled with a sand filter in oil removal from oilfield produced water (OPW) and synthetic produced water (SOPW). This paper investigated the influence of process parameters such as physical characteristics of sand, column height, types of effluent (oilfield produced water and synthetic produced water), and oil concentration on oil removal efficiency. An OPW sample was taken from effluents of the oilfield unity located at Rio Grande do Norte State (Brazil), and the SOPW sample was prepared using two types of oils and salts $(\mathrm{NaCl}$ and $\mathrm{KCl})$. The results showed that the oil concentration decreased significantly after the filtration process. The oil removal efficiency was influenced by the sand particle size and bed height, reaching $90 \%$ using a $30 \mathrm{~cm}$ high sand bed composed by mixed grain sizes.
\end{abstract}

\section{KEYWORDS}

oilfield produced water; sand filter; oil removal

\footnotetext{
${ }^{1}$ To whom all correspondence should be addressed.

Address: Universidade Federal de Santa Maria, Departamento de Engenharia Química, Avenida Roraima, 1000, Cidade Universitária, Camobi, Santa Maria - RS - Brasil.

ZIP Code: 97105-900 | Telephone: +55 (55) 3220-8448|e-mail: efoletto@gmail.com doi:10.5419/bjpg2016-0013
} 


\section{INTRODUCTION}

A common by-product of oil and gas production (onshore and offshore) is the oilfield produced water (OPW), which is carried out along with the produced fluids. Produced water can occur naturally, in geological formations (formation water) or as a result of water injection, and can also be a mixture of both (Veil et al., 2004). Another source of OPW is condensed water from gas production (OGP, 2002; Vegueria et al., 2002). An important characteristic of OPW is its complex chemical composition, which depends strongly on its origin. Chemical compounds present in OPW include dissolved hydrocarbons, organic acids, phenols, metals, traces of chemical products, and dispersed oil (Utvik, 1999). In general, the organic constituents of produced water can be distributed into three categories, namely hydrocarbons dissolved in water, dispersed hydrocarbons used in wastewater treatment or water-oil separation, and dissolved organic compounds such as phenols and acids (OGP, 2005). Other factors that affect the composition of OPW are the hydrocarbon composition and the daily activities involved in oil exploration and exploitation (Hayes \& Arthur, 2004). Therefore, the removal of dispersed and soluble hydrocarbons from the OPW is a major environmental challenge. In the USA, the Environmental Protection Agency (EPA) sets a monthly maximum of $29 \mathrm{mg} \mathrm{L}^{-1}$ of oil and grease in wastewater and a daily maximum of $42 \mathrm{mg} \mathrm{L}^{-1}$ (USEPA, 2007), while in the Gulf of Mexico and North Sea the monthly maximum allowed is 40 and $30 \mathrm{mg} \mathrm{L}^{-1}$, respectively (Gabardo et al., 2005). In Brazil, the total oil and grease (TOG) concentration level allowed for wastewater disposal in salt water is a maximum of $20 \mathrm{mg} \mathrm{L}^{-1}$ (CONAMA, 2011).

There are different types of primary OPW treatments to remove dispersed oil such as filtration, membrane processes, hydrocyclones, and centrifugation. Among them, the filtration process is considered an efficient and low-cost alternative for reducing the turbidity in aqueous suspensions. The filtration consists of a physical separation process, in which dispersed compounds are removed when are passed through a porous medium, retaining them and forming a separate phase known as the cake phase (Geankoplis, 2003). The separation of impurities by filtration process is associated to different mechanisms such as transport, interception, aggregation, sedimentation, and diffusion (Ives, 1970). The use of sand filters is recommended for treating waters while retaining organic matter (Vermerein \& Jobling, 1984; Dasberg \& Bressler, 1985; Ramadan, 2015; Simate, 2015; Grace et al., 2016). The good performance of the sand filter in retaining the organic matter, compared to other filters, is due to its ability to collect the contaminants throughout the sand bed (Keller \& Bliesner, 1990).

The sand filter has been used widely in treating residual waters (Hamoda et al., 2004; Rodgers et al., 2005; Rolland et al., 2009; Zheng et al., 2009; D'Alessio et al., 2015; Tonon et al., 2015; Latrach et al., 2016; Oladoja et al., 2016; Zheng et al., 2016; Zipf et al., 2016). Cha et al. (2010) obtained satisfactory results in removing oil from produced water, but assessed the combined processes of ozonization and filtration. However, sand filter has not yet been used as filtering medium for the oil removal from oilfield and synthetic oil produced water.

In this context, the aim of this work was to determine the efficiency of a sand filter in removing the oil and grease from oilfield and synthetic oil produced water. This work investigates the effect of parameters such as physical characteristics of sand, column height, type of effluent (oilfield produced water and synthetic produced water), and oil concentration on oil removal efficiency.

\section{MATERIAL AND METHODS}

\subsection{Experimental apparatus and oilfield produced water samples}

The filtration system used consisted of a glass column (height $=40 \mathrm{~cm}$, diameter $=10 \mathrm{~cm}$ ). The upper part of the column was filled gravitationally with sand and gravel. The lower part, a $10 \mathrm{~cm}$ support layer, was composed by coarse gravel. Coarse gravel was used as a support layer for the sand filter. In order to evaluate the efficiency of TOG removal, two filtration systems were used in this work: one mixed-media filter, consisting of four sand layer with grain sizes arranged in the sequence $12 / 16,20 / 28,35$, and $12 / 16$ mesh (as shown in Figure 1), and another consisting of sand bed with a fixed grain size of $12 / 16$ mesh. The sand beds used were 15 and $30 \mathrm{~cm}$ high for both 


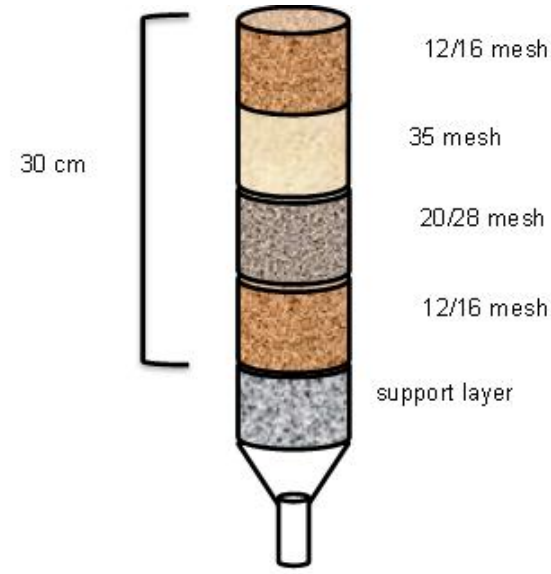

Figure 1. Schematic diagram of a mixed grain size filter.

systems. To optimize the filtration process through experimental design, the efficiency of TOG removal was investigated using solely SOPW. In the latter case, a sand bed (15 and $30 \mathrm{~cm}$ high) with a fixed grain size of $12 / 16$ mesh was used. The sand fractions were selected using a set of Tyler sieves. After the different grain sizes were selected, the sand was washed several times to remove impurities. The sand samples were oven dried at $100{ }^{\circ} \mathrm{C}$ for $24 \mathrm{~h}$. The gravel was washed and also then dried at $100{ }^{\circ} \mathrm{C}$, for $12 \mathrm{~h}$.

Table 1. Characteristics of the oilfield produced water from operating unity RN/CE (Brazil).

\begin{tabular}{|c|c|}
\hline Parameters & Concentration range \\
\hline Nitrate $\left(\mathrm{mg} \mathrm{L}^{-1}\right)$ & $0.75-3.0$ \\
\hline Chloride $\left(\mathrm{mg} \mathrm{L}^{-1}\right)$ & $737-2,949$ \\
\hline Salinity (mg L $\left.\mathrm{L}^{-1}\right)$ & $1,331-5,327$ \\
\hline $\mathrm{pH}$ & $7-7.6$ \\
\hline Turbidity (NTU) & $30-120$ \\
\hline Conductivity $\left(\mathrm{mS} \mathrm{cm}^{-1}\right)$ & $1.75-7.12$ \\
\hline Potassium (mg L $\left.{ }^{-1}\right)$ & $4.48-17.9$ \\
\hline Iron $\left(\mathrm{mg} \mathrm{L}^{-1}\right)$ & $0.005075-0.0203$ \\
\hline Nickel $\left(\mathrm{mg} \mathrm{L}^{-1}\right)$ & $0.0025-0.01$ \\
\hline Copper (mg L $\left.{ }^{-1}\right)$ & $0.5753-2.301$ \\
\hline Cadmium (mg L ${ }^{-1}$ ) & $0.0225-0.09$ \\
\hline Sodium (mg L ${ }^{-1}$ ) & $3.25-13$ \\
\hline Calcium (mg L $\mathrm{L}^{-1}$ ) & $10-40$ \\
\hline TOG (mg L $\left.{ }^{-1}\right)$ & $32-500$ \\
\hline
\end{tabular}

The synthetic oil produced water (SOPW) was prepared from a mixture containing $4 \mathrm{~L}$ of distilled water, $8 \mathrm{~g}$ of salts ( $\mathrm{NaCl}$ and $\mathrm{KCl}, 1: 1)$, and different oil concentrations. The oil sample consisted of a 1:1 mixture of 15 and $22^{\circ}$ API crudes. The mixture was obtained by mechanical agitation (Turratec/Tecnal agitator) for $30 \mathrm{~min}$, at $25{ }^{\circ} \mathrm{C}$, and $27,000 \mathrm{rpm}$. One liter of suspension was used for each test. The oilfield produced water (OPW) was obtained from a wastewater treatment plant of an operational unity located in Northeast Region of Brazil. Samples were collected at the outlet of the oil-water separator and conserved according to the standard methods established by the American Public Health Association, the APHA (1998).

\subsection{Analytical procedures}

The total oil and grease (TOG) concentration in the samples of synthetic and oilfield produced water (SOPW and OPW) before and after the filtration was determined using an InfraCal analyzer (Wilks enterprise Corp, model HATR-T2 TOG/TPH). This parameter was measured by spectrophotometry in the infrared region, based on the absorbance of $\mathrm{C}-\mathrm{H}$ bonds (USEPA methods 4.12.2 and 418.1). The grain size distribution of the sand sample was performed by a laser granulometer (Cibas, model 920). Oilfield produced water (OPW) was characterized given its variable composition. Copper, sodium, iron, potassium, cadmium, nickel, and calcium contents were determined using flame atomic absorption spectrophotometry (Varian, model AA240). A multiparametric probe (TROLL, model 9500) was used to determine nitrate, turbidity, $\mathrm{pH}$, conductivity and chloride. The salinity was calculated using Equation 1, based on chloride concentration in the sample (APHA, 1998).

Salinity $=1.80655\left[\mathrm{Cl}^{-}\right]$

Where $=\left[\mathrm{Cl}^{-}\right]$is the chloride concentration $\left(\mathrm{mg} \mathrm{L}^{-1}\right)$.

\section{RESULTS AND DISCUSSION}

\subsection{Characterization of OPW}

The main characteristics of the oilfield produced water are presented in Table 1. This produced water does not meet the legal requirements in both Brazil and the U.S., because the TOG 


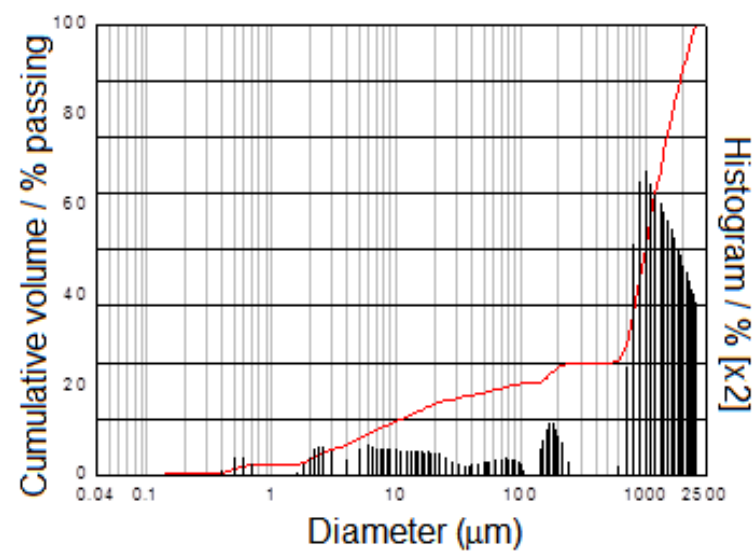

(a)

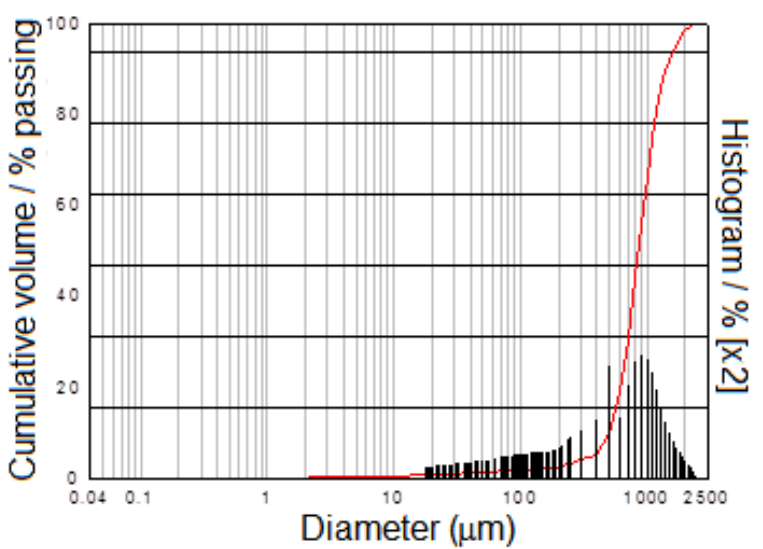

(b)

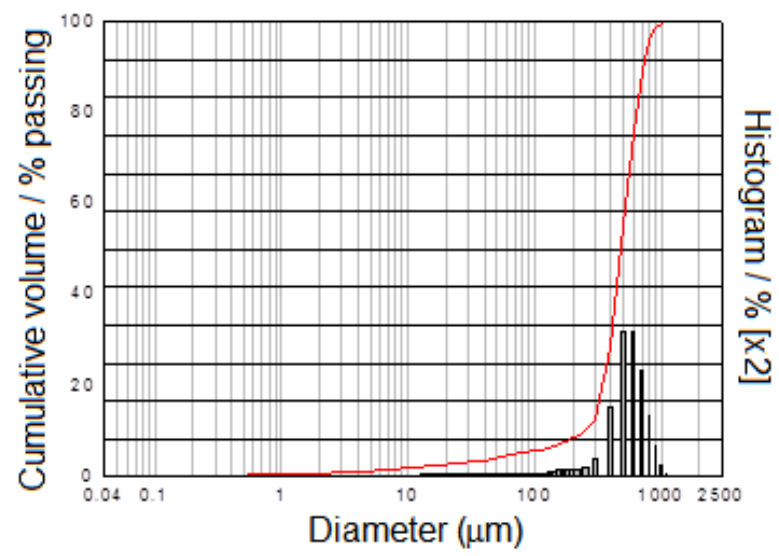

(c)

Figure 2. Particle size distribution curves of the sand samples (a) 12/16mesh, (b) 20/28 mesh, and (c) 35 mesh.

concentration is higher than the minimum value allowed by CONAMA ( $20 \mathrm{mg} \mathrm{L}^{-1}$ ) and USEPA ( $29 \mathrm{mg}$ $\left.\mathrm{L}^{-1}\right)$. Produced water has a very variable composition, which depends on the characteristics of the production oilfield as well as the nature of injected fluids. The chloride concentration (737 $2,949 \mathrm{mg} \mathrm{L}^{-1}$ ) of our sample, for example, is lower when compared to the data obtained for a produced water from an onshore oilfield in the United States (Murray-Gulde et al., 2003) and one in Bacia de Campos offshore oilfield, Brazil (Lima et al., 2008), with concentrations of 3,361 and 29,830 $\mathrm{mg} \mathrm{L}^{-1}$, respectively. Moreover, the $\mathrm{pH}(7-7.5)$ was between neutral and slightly basic, similar to the ones obtained for the Devecatagi oil production well $(\mathrm{pH}=7.1)$ and those for Vakiflar gas and oil production well $(\mathrm{pH}=7.8$ ), in Turkey (Çakmakce et al., 2008). The produced water from the Curimã platform (Petrobras, Potiguar Basin, State of Ceará/Brazil), which disposes around $1000 \mathrm{~m}^{3}$ day $^{-1}$ (mean in 2004), exhibited a pH of around 8.7, differing completely from our produced water sample. Among the various inorganic components present in produced water, the most representative elements are $\mathrm{K}^{+}, \mathrm{Na}^{+}$, and $\mathrm{Ca}^{2+}$, at high concentrations (Arnold \& Stwart, 2008). Regarding heavy metals, cadmium, lead, nickel, zinc, and chromium are the ones with the highest concentrations (Neff, 1987). Therefore, these heavy metals deserve more attention, since they impact not only the environment, but also human health (Chen et al., 2012; Balistriere \& Mebane, 2014). It is important to underscore that the copper concentration is higher than the minimum value allowed by CONAMA $\left(0.001 \mathrm{mg} \mathrm{L}^{-1}\right)$.

\subsection{Characterization of sand bed}

Grain size and frequency distribution in sand samples are represented by granulometric curves, shown in Figure 2. Thus, the sand samples retained 
Table 2. Parameters of sand bed.

\begin{tabular}{lccccc}
\hline Particle size (mesh) & ${ }^{1} \mathrm{C}_{\mathrm{u}}$ & $\mathrm{D} 10$ & $\mathrm{D} 30$ & $\mathrm{D} 60$ & ${ }^{2} \mathrm{C}_{\mathrm{c}}$ \\
\hline $12 / 16$ & 1.38 & 1.95 & 2.40 & 2.71 & 1.08 \\
$20 / 28$ & 1.35 & 1.37 & 1.70 & 1.90 & 1.11 \\
35 & 1.22 & 0.49 & 0.56 & 0.60 & 1.06 \\
\hline${ }^{1} \mathrm{C}_{\mathrm{u}}=$ Coefficient of uniformity & & & &
\end{tabular}

Table 3. Real and coded (in parentheses) variables and results for the experimental design.

\begin{tabular}{lccc}
\hline Run & Height $(\mathrm{cm})$ & Concentration $\left(\mathrm{mg} \mathrm{L}^{-1}\right)$ & $y_{i}(\varepsilon, \%)$ \\
\hline 1 & $15(-1)$ & $204(+1)$ & 61.4 \\
2 & $30(+1)$ & $204(+1)$ & 73.7 \\
3 & $15(-1)$ & $101(-1)$ & 50 \\
4 & $30(+1)$ & $101(-1)$ & 76 \\
5 & $15(-1)$ & $201(+1)$ & 57 \\
6 & $30(+1)$ & $204(+1)$ & 70 \\
7 & $15(-1)$ & $101(-1)$ & 50 \\
8 & $30(+1)$ & $101(-1)$ & 78.3 \\
\hline
\end{tabular}

in the sieves with $12 / 16,20 / 28$, and 35 meshes have a mean diameter of 997,902 , and $479 \mu \mathrm{m}$, respectively. The high mean diameter values $(>100$ $\mu \mathrm{m}$ ) indicate the presence of void spaces between sand grains, which allows better penetration and distribution of the wastewater flow along the entire bed.

Figure 2 shows D10, D30, and D60, corresponding to $10 \%, 30 \%$, and $60 \%$ particles with smaller diameters, presented in Table 2, along with other physical characteristics of the three sand grain sizes used in the filter, i.e., coefficient of curvature $\left(C_{c}\right)$ and coefficient of uniformity $\left(C_{u}\right)$. According to the American Society for Testing Materials (ASTM), the $12 / 16$ mesh grain size $(4-2$ $\mathrm{mm}$ ) is classified as coarse sand, and the 20/35 mesh $(2-0.425 \mathrm{~mm})$, as medium sand. Also, according to the ASTM, the coefficient of uniformity $\left(C_{u}=D 60 / D 10\right)$, which allows assessing the distribution of sand particle size, should be between 4 and 6 to indicate uniform distribution. Regarding to the sand bed, the coefficient of uniformity was around 1.0 for all grain size ranges, and therefore exhibiting non-uniform distribution, corroborating the results showed in particle size distribution curves (Figure 2). In regards to the coefficient of curvature $\left(C_{C}=(D 30)^{2} / D 60 \times D 10\right)$, the values were approximately 1.0 , indicating a proportional distribution of particle size, being that the void spaces left among larger particles can be occupied by smaller particles. This makes the bed more suitable for slow filtration, which, in turn, provides better oil removal.

\subsection{Experimental design}

To optimize the filtration process, considering sand bed height and initial TOG concentration on the removal efficiency of SOPW, a $2^{2}$ factorial design was carried out in duplicate, with eight experiments (Table 3). This factorial has two factors (bed height and initial concentration of TOG) and two levels for each factor, the lowest level (-) and the highest level (+). The bed height ranged from 15 to $30 \mathrm{~cm}$ and the initial concentration of TOG ranged from 101 to $204 \mathrm{mg} \mathrm{L}^{-}$ $\left.{ }^{1}\right)$. The response variable was the TOG removal efficiency $(\varepsilon, \%)$ named $y_{i}$. The essays were performed randomly. The number of experimental points (eight) was delineated as enough to assess the linear model.

Based on statistical modeling, a linear mathematical model was proposed (Equation 2):

$y_{i}=64.55+0.979 x_{1}+9.946 x_{2}-3.628 x_{1} x_{2}$

Where $x_{1}$ is the oil concentration, $x_{2}$ is the bed height, and $y_{i}$ corresponds to TOG removal efficiency. 
Table 4. Variance analysis for adjusting the linear model.

\begin{tabular}{lccccc}
\hline Source of variation & QS & DF & MS & $\mathrm{F}_{\text {calculated }}$ & $\mathrm{F}_{\text {calculated }} / \mathrm{F}_{\text {value }}$ \\
\hline Regression & 904.43 & 3 & 301.47 & 62.47 & 9.48 \\
Residual & 19.30 & 4 & 4.82 & & \\
Total & 923.73 & & & & \\
\hline QS = Quadratic sum & & & & \\
DF = Degrees of freedom & & & & \\
MS = Mean square & & & & \\
$\mathrm{F}_{\text {calculated }}=\mathrm{MS}_{\text {Regression }} / \mathrm{MS}_{\text {Residual }}$ & & &
\end{tabular}

The validity of the model was verified using Analysis of Variance (ANOVA), as shown in Table 4. The coefficient of determination $\left(R^{2}\right)$ was applied to evaluate model fit to experimental data. The closer $R^{2}$ is to 1 , the better the correlation between values calculated by the model and those observed in the experiments is.

The F-value calculated was compared to critical F-value at a $95 \%$ confidence level. Table 4 show that the linear model (Equation 2) obtained is significant at a 95\% confidence level ( $F_{\text {calculated }}$ greater than $\left.F_{\text {critical }}\right)$. In addition, the correlation coefficient $\left(R^{2}\right)$ reached 0.9791 , indicating that the model explains $97.91 \%$ of the variation in experimental data. The $F_{\text {calculated }}$ was 9.5 times higher than $F_{\text {critical }}$ implying that the proposed model can be considered predictive, significant, and, therefore, adequate to describe the response variable as a function of the factors (Silva et al.,
2015; Anchieta et al., 2016). Figure 3 shows the response surface and the Pareto chart determined from experimental design. Factorial experimental design allowed determining the effects of initial TOG concentration and the sand bed height on the oil and grease removal efficiency in SOPW.

The height and concentration variations in the maximum removal region (optimal region), Figure $3 a$, provide an analysis of the response tendency of the dependent variable (efficiency) predicted by the model (Equation 2). They suggest that the efficiency of removing the TOG from SOPW increases with the increase of sand bed height. Furthermore, the initial concentration of TOG does not affect the overall removal efficiency in the range of oil concentration (101 and $204 \mathrm{mg} \mathrm{L}^{-1}$ ) and bed height $(15$ and $30 \mathrm{~cm}$ ) studied. The Pareto chart (Figure 3b) shows statistically significant effects. According to results, the significant effects

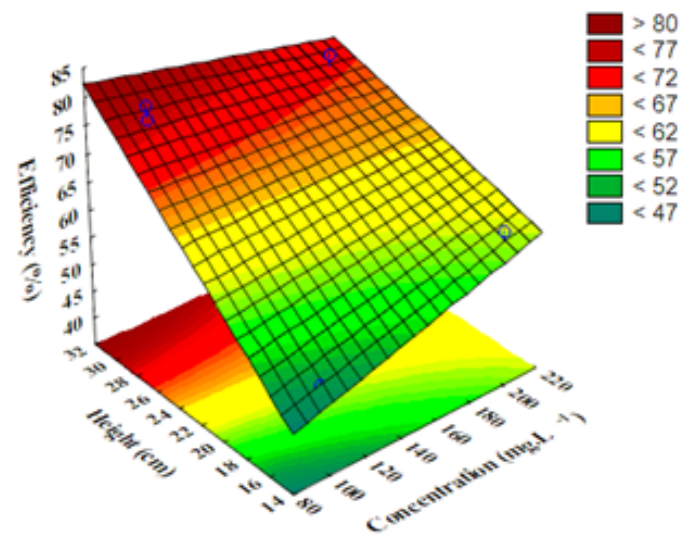

(a)

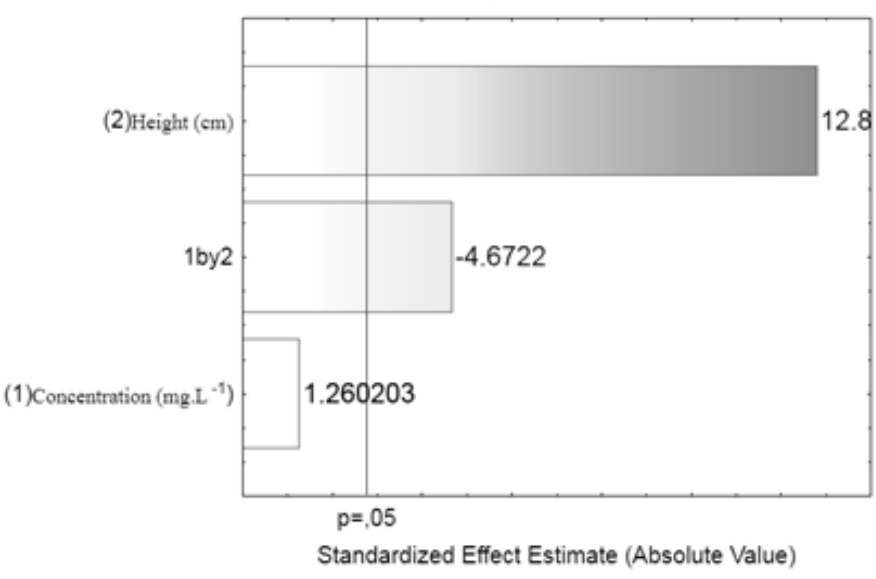

(b)

Figure 3. Response surface (a) and Pareto chart (b) for factorial experimental design. 


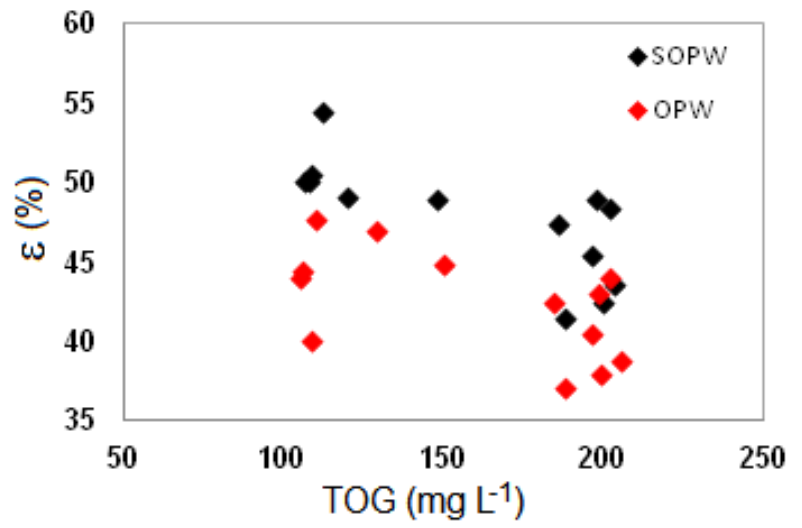

(a)

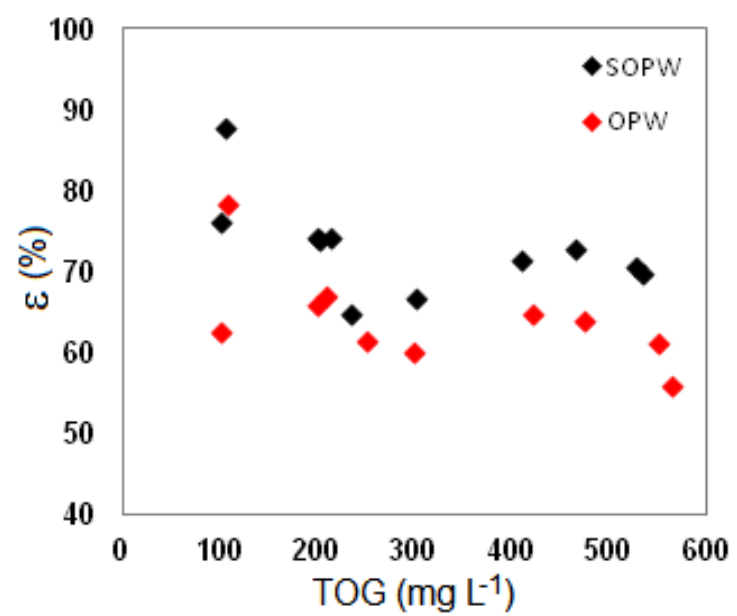

(b)

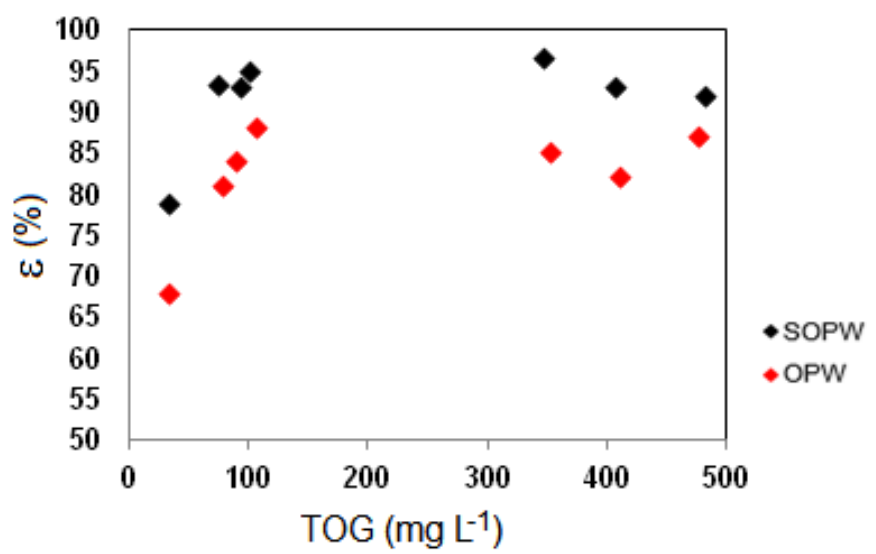

(c)

Figure 4. Removal efficiency of TOG from SOPW and OPW using (a) sand bed $15 \mathrm{~cm}$, (b) sand bed $30 \mathrm{~cm}$, and (c) mixed grain size.

are height of the sand bed and interaction between it and initial concentration of TOG, which act positively on filtration efficiency.

\subsection{Filtration efficiency}

The filtration was assessed in terms of the efficiency of oil removal and the consequent reduction of TOG concentration in OPW and SOPW. The TOG removal efficiency $(\varepsilon, \%)$ was calculated from Equation 3:

$\varepsilon(\%)=\frac{\mathrm{TOG}_{0}-\mathrm{TOG}_{\mathrm{F}}}{\mathrm{TOG}_{0}} \times 100$

Where $=\varepsilon(\%)$ is the removal efficiency of TOG. $\mathrm{TOG}_{0}$ and $\mathrm{TOG}_{\mathrm{F}}$ are initial and final concentrations of total oil and greases $\left(\mathrm{mg} \mathrm{L}^{-1}\right)$, respectively.
In the $15 \mathrm{~cm}$-high sand bed with a fixed grain size of 12/16 mesh (Figure 4a), TOG removal from SOPW was around 50\%, whereas for oil field wastewater a small reduction was obtained (40\%). The poor TOG removal efficiency observed for both wastewaters can be explained by the use of a lower sand bed height $(15 \mathrm{~cm})$. In the case of the $30 \mathrm{~cm}$ column (12/16 mesh) (Figure 4b), TOG removal efficiency for both wastewaters (OPW and SOPW) increased considerably ( $>60 \%)$, confirming that the bed size is an important parameter in the efficiency of the removal process. The experiment with the $30 \mathrm{~cm}$ sand bed with mixed grain size (in the sequence $12 / 16,20 / 28,35$, and 12/16 mesh) presented efficiency higher than $85 \%$ (Figure 4c), exhibiting better removal than experiments under other conditions. This confirms that the decrease in 
grain size along the bed is an important factor in filtration. The enhanced removal in relation to the smaller particle size may be due to their smaller effective diameter (D10), resulting in a slower filtration speed and consequent improvement in quality, since permeability tends to decrease as fine particles fill the empty spaces (Fang \& Daniels, 2006). A similar filtration process was used by Cha et al. (2010), however associated with the ozonation method. The authors did not evaluate the TOG removal, but the turbidity of the effluent was reduced from 200 to 2 NTU. The best removal results were observed when using a mixed grain size filter (Figure 4b), reaching efficiency higher than $90 \%$. Under all the experimental conditions tested, the efficiency in removing the TOG from synthetic oilfield produced water (SOPW) was greater than that of oilfield produced water (OPW), given that the synthetic wastewater exhibits a less complex composition.

\section{CONCLUSIONS}

The filtration process with a fixed sand bed proved to be an efficient alternative for removing oil and grease from oilfield produced water. For both synthetic and oilfield produced water (SOPW and OPW, respectively), a significant reduction in oil and grease was obtained. The $30 \mathrm{~cm}$ bed was more efficient than its $15 \mathrm{~cm}$ counterpart, indicating that removal efficiency depends on the bed height. In regards to grain size, the use of sand with different grain sizes resulted in greater TOG removal efficiency. Oilfield wastewater removal efficiency was slightly lower than that of the synthetic wastewater. According to statistical factorial design, the height of the bed was the most significant variable, but the concentration also had a significant effect on the results when combined with bed height.

\section{ACKNOWLEDGEMENTS}

The authors would like to acknowledge the financial support provided by the Brazilian agency ANP (Agência Nacional do Petróleo, Gás Natural e Biocombustíveis), and the technical support provided by Federal University of Rio Grande of Norte (Brazil).

\section{REFERENCES}

Anchieta, C. G.; Dotto, G. L.; Mazutti, M. A.; Kuhn, R. C.; Collazzo, G. C.; Chiavone-Filho, O.; Foletto, E. L. Statistical optimization of Reactive Red 141 removal by heterogeneous photo-Fenton reaction using $\mathrm{ZnFe}_{2} \mathrm{O}_{4}$ oxide prepared by microwave irradiation. Desalination and Water Treatment, v. 57(33), p. 15603-15611, 2016. http://dx.doi.org/10.1080/19443994.2015.1070761

APHA - American Public Health Association (1998); American Water Works Association, Water Environmental Federation Standard methods for examination of water and wastewater, $20^{\text {th }}$ ed Washington. Available at:

http://www.standardmethods.org. Accessed on: 14 May 2016.

Arnold, K.; Stwart, M. Produced water treating systems. In: Surface Production Operations, $3^{\text {th }}$ ed, USA: Gulf Professional publishing, 482-609, 2008. http://dx.doi.org/10.1016/B978-075067853-7.50012-0

Balistriere, L. S.; Mebane, C. A. Predicting the toxicity of metal mixtures. Science of the Total Environmental, v. 466-467, p. 788-799, 2014. http://dx.doi.org/10.1016/i.scitotenv.2013.07.034

Çakmakce, M.; Kayaalp, N.; Koyuncu, I. Desalination of produced water from oil product fields by membrane processes. Desalination, $v$. 222, p. 176-186, 2008. http://dx.doi.org/10.1016/i.desal.2007.01.147

Cha, Z.; Lin, C.; Cheng, C.; Andy, H. P. K. Removal of oil sheen from produced water by pressureassisted ozonation and sand filtration. Chemosphere, v. 78, p. 583-590, 2010.

http://dx.doi.org/10.1016/i.chemosphere.2009.10.051

Chen, J. H.; Ni, J. C.; Liu, Q. L.; Li, S. X. Adsorption behavior of $\mathrm{Cd}$ (II) ions on humic acid-immobilized sodium alginate and hydroxyl ethyl cellulose blending porous composite membrane adsorbent. Desalination. v. 285, p. 54-61, 2012. http://dx.doi.org/10.1016/i.desal.2011.09.033

CONAMA - Conselho Nacional do Meio Ambiente (Brasil). Resolution no 430 (2011). Disposes of the conditions of effluent discharges. Available at:

http://www.mma.gov.br/port/conama. Accessed on: 14 May 2016. (in Portuguese). 
D'Alessio, M.; Yoneyama, B.; Kirs, M.; Kisand, V.; Ray, C. Pharmaceutically active compounds: Their removal during slow sand filtration and their impact on slow sand filtration bacterial removal. Science of the Total Environment, v. 524-525, p. 124-135, 2015.

http://dx.doi.org/10.1016/i.scitotenv.2015.04.014

Dasberg, S.; Bressler, E. Drip Irrigation Manual. Bet Dagan: International Information Center, 95, 1985.

Fang, H.; Daniels, J. Introductory Geotechnical Engineering: an environmental perspective. $1^{\text {th }} \mathrm{ed}$, New York: CRC Press, 2006.

http://dx.doi.org/10.4324/9780203403525

Gabardo, I. T.; Platte, E. B.; Lima, E. F.; Andrade, F. B. Caracterização do efluente da plataforma Curimã (PCR - 1). Centro de Pesquisa e Desenvolvimento Leopoldo A. Miguel de Melo, Petrobras, Brazil, 2005. (in Portuguese).

Geankoplis, C. Transport Process and separation Process Principles. $4^{\text {th }}$ ed, USA: Prentice Hall, p. 904, 2003.

Grace, M. A.; Healy, M. G.; Clifford, E. Performance and surface clogging in intermittently loaded and slow sand filters containing novel media. Journal of Environmental Management, $\mathrm{v}$. 180, p. 102-110, 2016.

http://dx.doi.org/10.1016/i.jenvman.2016.05.018

Hamoda, M. F.; Al-Ghusain, I.; Al-Mutairi, N. Z. Sand filtration of wastewater for tertiary treatment and water reuse. Desalination, v. 164, p. 203-211, 2004. http://dx.doi.org/10.1016/50011-9164(04)00189-4

Hayes, T.; Arthur, D. Overview of emerging produced water treatment Technologies. In: The $1^{\text {th }}$ Annual International Petroleum Environmental Conference. Albuquerque, New Mexico, 12-15/October, 2004.

Ives, K. J. Rapid filtration. Water research, v. 4, p. 201-223, 1970. http://dx.doi.org/10.1016/00431354(70)90068-0

Keller, J.; Bliesner, R. D. Sprinkle and trickle irrigation. New York: Van Nostrand Reinhold, 625, 1990. http://dx.doi.org/10.1007/978-1-4757-1425-8
Latrach, L.; Ouazzani, N.; Masunaga, T.; Hejjaj, A.; Bouhoum, K.; Mahi, M.; Mandi, L. Domestic wastewater disinfection by combined treatment using multi-soil-layering system and sand filters (MSL-SF): A laboratory pilot study. Ecological Engineering, v. 91, p. 294-301, 2016. http://dx.doi.org/10.1016/i.ecoleng.2016.02.036

Lima, R. M. G.; Wildhagen, G. R. S; Cunha, J. W. S. D. Remoção do íon amônio de águas produzidas na exploração de petróleo em áreas offshore por adsorção em clinoptilolita. Química Nova, v. 31, p. 1237-1248, 2008. (in Portuguese).

http://dx.doi.org/10.1590/\$0100-40422008000500054

Murray-Gulde, C.; Heatly, J. E.; Karanfil, T.; Rodgers, J. H.; Mayers, J. E. Performance of hybrid reverse osmosis - constructed wetland treatment system for brackish oil field produced water. Water Research, v. 37, p. 705-713, 2003.

http://dx.doi.org/10.1016/S0043-1354(02)00353-6

Neff, J. M. Biological effects of drilling fluids drill cutting and produced waters. Long-term Environmental Effects of offshore oil and gas development. London: Elsevier Applied Science Publishers, LTD, 1987.

OGP - International Association of Oil and Gas Producers (2002). Aromatics in produced water: occurrence, fate $\&$ effects, and treatment. Report n. 1.20/324. Available at: http://www.ogp.org.uk/pubs/324.pdf. Accessed on: 14 Jun 2016.

OGP - International Association of Oil and Gas Producers (2005). Fate and effects of naturally occurring substances in produced water on marine environment. Report $n$. 364. Available at: http://www.ogp.org.uk/pubs/364.pdf. Accessed on: 14 Jun 2016.

Oladoja, N. A.; Liu, Y.; Drewes, J. E.; Helmreich, B. Preparation and characterization of a reactive filter for groundwater defluoridation. Chemical Engineering Journal, v. 283, p. 1154-1167, 2016. http://dx.doi.org/10.1016/i.cej.2015.08.059

Ramadan, M. Efficiency of new Miswak, titanium dioxide and sand filters in reducing pollutants from wastewater. Beni-Suef University Journal of Basic and Applied Sciences, v. 4, p. 4751, 2015.

http://dx.doi.org/10.1016/i.bjbas.2015.02.007 
Rodgers, M.; Healy, M. G.; Mulqueen, J. Organic carbon removal and nitrification of high strength wastwater using stratified sand filters. Water Research, v. 39, p. 327-3286, 2005. http://dx.doi.org/10.1016/i.watres.2005.05.035

Rolland, L.;Molle, P.; Liénard, A.; Bouteldja, F.; Grasmick, A. Influence of the physical and mechanical characteristics of sand on the hydraulic and biological behaviors of sand filters. Desalination, v. 248, p. 998-1007, 2009. http://dx.doi.org/10.1016/i.desal.2008.10.016

Silva, S. S.; Chiavone-Filho, O.; Barros Neto, E. L.; Foletto, E. L. Oil removal from produced water by conjugation of flotation and photo-Fenton processes. Journal of Environmental Management, v. 147, p. 257-263, 2015.

http://dx.doi.org/10.1016/i.jenvman.2014.08.021

Simate, G. S. The treatment of brewery wastewater for reuse by integration of coagulation/flocculation and sedimentation with carbon nanotubes 'sandwiched' in a granular filter bed. Journal of Industrial and Engineering Chemistry, v. 21, p. 1277-1285, 2015. http://dx.doi.org/10.1016/i.jiec.2014.06.001

Tonon, D.; Tonetti, A. L.; Coraucci Filho, B.; Bueno, D. A. C. Wastewater treatment by anaerobic filter and sand filter: Hydraulic loading rates for removing organic matter, phosphorus, pathogens and nitrogen in tropical countries. Ecological Engineering, v. 82, p. 583-589, 2015. http://dx.doi.org/10.1016/i.ecoleng.2015.05.018

USEPA - United States Environmental Protection Agency. Oil and Gas Extraction Point Source Category (Part 435), 40 CFR, Fed. Reg. 29, 294-344, 2007. Available at: http://www3.epa.gov. Accessed on: 14 Jun 2016.

Utvik, T. I. R. Chemical characterization of produced water from four offshore oil production platforms in the Northsea. Chemosphere, v. 39, p. 2593-2606, 1999. http://dx.doi.org/10.1016/S0045$\underline{6535(99) 00171-X}$
Vegueria, S. F. J.; Godoy, J. M.; Miekeley, N. Environmental impact studies of barium and radium discharges by produced waters from the "Bacia de Campos" Oil - field offshore platforms, Brazil. Journal of Environmental Radioactivity, v. 62, p. 29-38, 2002. http://dx.doi.org/10.1016/\$0265$\underline{931 \times(01) 00148-5}$

Veil, J. A.; Puder, M. G.; Elcock, D.; Redweik, R. J. A white paper describing produced water from production of crude oil natural gas, and coal bed methane. U. S. Department of Energy - National Energy Technology Laboratory. Under Contract W31-109-Eng-38, 2004. Available at: http://s3.amazonaws.com/propublica/assets/natur al_gas/doe_produced_water_2004.pdf. Accessed on: 14 Jun 2016.

Vermerein, L.; Jobling, G. A. Localized irrigation. Irrigation and Drainage, Paper 36, Rome, Italy: FAO, 1984.

Zheng, D.; Liu, G.; Deng, L.; Liu, Y.; Yang, H.; Wang, L.; Song, L.; Pu, X.; Wang, Z.; Zhang; Y. Startup strategy for partial nitritation treatment of anaerobically digested effluent of swine wastewater in a sand filter. Ecological Engineering, v. 93, p. 13-17, 2016.

http://dx.doi.org/10.1016/j.ecoleng.2016.05.006

Zheng, X.; Mehrez, R.; Jekel, M.; Ernst, M. Effect of slow sand filtration of treated wastewater as pre-treatment to UF. Desalination, v. 249, p. 591595, 2009.

http://dx.doi.org/10.1016/i.desal.2008.12.052

Zipf, M. S.; Pinheiro, I. G.; Conegero, M. G. Simplified greywater treatment systems: Slow filters of sand and slate waste followed by granular activated carbon. Journal of Environmental Management, v. 176, p. 119-1271, 2016. http://dx.doi.org/10.1016/j.jenvman.2016.03.035 